\title{
THE WELL-BEING OF RETIREES: EVIDENCE USING SUBJECTIVE DATA
}

\author{
Keith A. Bender* \\ CRR WP 2004-24 \\ Released: November 2004 \\ Draft Submitted: October 2004
Center for Retirement Research at Boston College
550 Fulton Hall
140 Commonwealth Ave.
Chestnut Hill, MA 02467
http://www.bc.edu/crr \\ Tel: 617-552-1762 Fax: 617-552-1750
}

* Keith A. Bender is an assistant professor in the Department of Economics and Graduate Program in Human Resources and Labor Relations at the University of Wisconsin-Milwaukee. The research reported herein was performed pursuant to a grant from the U.S. Social Security Administration (SSA) to the Center for Retirement Research at Boston College (CRR). This grant was awarded through the CRR's Steven H. Sandell Grant Program for Junior Scholars in Retirement Research. The opinions and conclusions are solely those of the author and should not be construed as representing the opinions or policy of SSA or any agency of the Federal Government or the CRR. The author wishes to thank Elena Ermolenko for her excellent research assistance and John S. Heywood for extremely helpful discussions in this project.

(C) 2004, by Keith A. Bender. All rights reserved. Short sections of text, not to exceed two paragraphs, may be quoted without explicit permission provided that full credit, including () notice, is given to the source. 


\title{
About the Sandell Grant Program
}

This paper received funding from the Steven H. Sandell Grant Program for Junior Scholars in Retirement Research. Established in 1999, the Sandell program's purpose was to promote research on retirement issues by junior scholars in a wide variety of disciplines, including actuarial science, demography, economics, finance, gerontology, political science, psychology, public administration, public policy, sociology, social work, and statistics. The program was funded through a grant from the Social Security Administration (SSA).

\section{About the Center for Retirement Research}

The Center for Retirement Research at Boston College, part of a consortium that includes a parallel centers at the University of Michigan and the National Bureau of Economic Research, was established in 1998 through a grant from the Social Security Administration. The goals of the Center are to promote research on retirement issues, to transmit new findings to the policy community and the public, to help train new scholars, and to broaden access to valuable data sources. Through these initiatives, the Center hopes to forge a strong link between the academic and policy communities around an issue of critical importance to the nation's future.

\author{
Center for Retirement Research at Boston College \\ 550 Fulton Hall \\ 140 Commonwealth Ave. \\ Chestnut Hill, MA 02467 \\ phone: 617-552-1762 fax: 617-552-1750 \\ e-mail: crr@bc.edu \\ http://www.bc.edu/crr
}

\section{Affiliated Institutions:}

American Enterprise Institute

Center for Strategic and International Studies

The Brookings Institution Massachusetts Institute of Technology

Max Planck Institute for Demographic Research

Syracuse University

Urban Institute 


\begin{abstract}
While previous economic research focuses on the financial well-being of retirees, this paper examines the determinants of overall well-being of retirees. Using data from the 2000 Health and Retirement Study, the strongest predictor of retirement well-being is the reason for entering retirement. If individuals were "forced" to retire, their well-being is significantly lower than those who chose to retire. This indicates the importance of expectations on retirement satisfaction. Additionally, health, current income, and comparison retirement income have important roles in determining overall well-being.
\end{abstract}




\section{THE WELL-BEING OF RETIREES: EVIDENCE USING SUBJECTIVE DATA}

\section{Introduction}

Financial or economic well-being in retirement has been of increasing interest for economic researchers. The policy implications are large. As the baby boom generation nears retirement, understanding the determinants of economic well-being enables policy makers to evaluate and possibly reform present retirement institutions, such as public and private pension programs, as well as potentially institute new institutions to meet the demands of the soon to be rapidly increasing retirement population. Of particular interest in this field has been the focus on retirement income adequacy, that is, the financial resources retirees need to be above some minimal level.

While this area of research is important, focusing on just the economic well-being of individuals may miss other factors that influence overall well-being. Indeed, there has been a lack of research on other aspects of well-being for retirees in the economics literature. This is a bit surprising given the recent increased interest by labor economists in examining the well-being of workers (i.e. overall job satisfaction or satisfaction with some aspect of the job such as pay, promotion prospects, etc.) and of people in general (i.e. life satisfaction). This paper offers an examination of the determinants of the overall well-being of retirees, using subjective measures of well-being from the 2000 Health and Retirement Study.

The paper is organized as follows. The next section reviews the economics literature on well-being measures, both in the job and in life. The third section explains the data and methodology used in the research, while the fourth section reviews the results. A final section summarizes the study and offers areas of future research.

\section{Literature Review}

Measures of retiree well-being have primarily focused on two economic measures of well-being. The most common metric is retirement income as summarized in Andrews (1993) and Radner (1998). ${ }^{1}$ The other common metric is examining wealth, generally financial assets, net housing value, and the present discounted value of Social Security retirement and pension benefits (see Levine et al., 2000). Regardless of the measure, the research on economic wellbeing often examines which factors lead to higher levels of retirement income and/or wealth, assuming that this leads to increased overall well-being. Other research, such as Haveman et al. (2003), examines the changes in these measures of economic well-being for retirees as they age. ${ }^{2}$

\footnotetext{
${ }^{1}$ OECD (2001) offers an interesting comparison of economic well-being of retirees across nine OECD countries: Canada, Finland, Germany, Italy, Japan, the Netherlands, Sweden, the UK, and the US.

${ }^{2}$ Of course, income per se is not likely to increase well-being. However, it can purchase goods and services that increase well-being. Therefore investigating consumption patterns of the retired, as in Bahizi (2003), might be an even better indicator of well-being.
} 
However, it is important to realize that economic well-being is only one dimension of overall well-being. Recent surveys by Frey and Stutzer (2002a and 2002b) summarize the mounting research on overall well-being (as measured by happiness or life satisfaction). Since a central tenet of economics is the maximization of utility by individuals, study of the closest proxy to utility, happiness or well-being, should be an area of keen economic interest. In referring to job satisfaction, a dimension of overall happiness, Hamermesh (2001, p2) states, "Only one measure, the satisfaction that workers derive from their jobs, might be viewed as reflecting how they react to the entire panoply of job characteristics. Indeed, a potentially useful view is that job satisfaction is the result of the worker's weighting in his/her own mind of all the job's aspects. It can be viewed as a single metric that allows the worker to compare the current job to other labor-market opportunities." Frey and Stutzer (2002b) identify areas where the study of happiness is important for economics: as a method to determine the efficiency of economic policy, the effect of institutions on individual well-being, and the relative importance of nonfinancial and financial variables on the formation of subjective well-being.

The studies of job satisfaction have been linked to several types of economic behavior. While self-reported measures of satisfaction have been criticized as subjective, Blanchflower and Oswald (1999) report that social psychologists have often found that job satisfaction measures correlate with many objective outcomes. For example, Moris ha (1986) and Clark et al. (1998) find that workers with lower self-reported job satisfaction have higher absenteeism and higher quit rates. Further, Iaffaldano and Muchinsky (1985) and Ostroff (1992) report that higher job satisfaction within a firm is positively correlated with its performance. Furthermore Rogers et al. (1994) find that job satisfaction is also correlated with increased customer satisfaction within service industries.

While there have been many studies on the determinants of life satisfaction (e.g. van Praag et al., 2002), only a couple have focused directly on the well-being of retirees. There has, however, been research on several related areas, namely the interrelationship of happiness and labor force status, age, and pensions. Below, I briefly review this literature before turning to the studies that examine retirement satisfaction.

Labor Force Status and Well-being. Recent studies examine the role of labor force status, particularly unemployment, on life satisfaction. Gerlach and Stephan (1996), Theodossiou (1998), and Winkelman and Winkelman (1998) find that unemployment lowers life satisfaction, even after controlling for income and the endogeneity of unemployment and happiness. Clark and Oswald (1994) identify unemployment as the single most important negative influence on life satisfaction, more important even than divorce.

Two papers focus primarily on retirement's influence on life satisfaction. First, Wottiez and Theeuwes (1998) examine Dutch data of 43 to 63 year olds and find that those who retired early have higher life satisfaction than workers, although normal aged retirees tend to have equal or lower life satisfaction compared to workers. In the second paper, Charles (2002) finds that retirement among men leads to lower life satisfaction. However, after controlling for endogeneity, he finds that retirement and life satisfaction are positively correlated. Neither study focuses directly on retiree well-being and its determinants but rather they compare the life satisfaction of retired to nonretired individuals. 
Age and Well-being. Another common finding is that the relationship between age and happiness is nonlinear. As in Clark and Oswald (1996) it is generally found to be U-shaped, that is, higher for younger and older individuals. These two age groups may have more alternatives for the use of their time compared to those working (e.g. education for the young and retirement for the old). Age might be a particularly important factor for the retired as it is related to the availability and generosity of Social Security and private pension benefits.

Pensions and Satisfaction There are at least two avenues through which pensions may affect life satisfaction. For many retirees, pensions provide a significant percentage of income in retirement (Wiatrowski, 1993) therefore their generosity should affect the happiness of the retired. Furthermore, while absolute income from pensions is certainly important in the determination of life satisfaction, relative income (how one worker's income from his/her pensions compares to income that otherwise similar workers get from their pensions) may also be important. The importance of relative or comparison income is well established in the job satisfaction literature (Clark and Oswald 1996), and it is likely to be important here too.

Other pension characteristics besides generosity may be important. Luchak and Gellatly (2002) find that increased pension accruals lead to lower job satisfaction. Their interpretation of this is that since receipt of pension benefits is risky (either because of accrual risk or job termination risk) higher accruals lead to more risk taken on by the worker which in turn lowers their job satisfaction. If this is true, then not only is the generosity of pension plans important, but characteristics of pension plans (e.g. whether it is a defined compensation or defined benefit plan) may play a role in the life satisfaction of retirees. Whether these characteristics are also important in retirement satisfaction will be explored below.

Retirement Satisfaction Research There have been three papers in the literature that directly examine retirement satisfaction. Shultz et al. (1998) examine the retirement satisfaction of early retirees from the first wave of the Health and Retirement Study (HRS) to examine the relative importance of "push" (e.g. poor health) and "pull" (e.g. leisure) factors on retirement satisfaction. For a relatively small sample of 827 early retirees, they find that push factors are more important for those who are involuntarily retired, pull factors tend to be more important for voluntarily retired. Key in their analysis is the focus on the voluntariness of retirement, although their study is limited in scope to early retirees.

Elder and Rudolph (1999) also use the first wave of the HRS to examine the role of financial planning and expectations on the retirement satisfaction of nearly 1,800 retirees. Although they examine a limited number of covariates, they do find a strong positive correlation between retirement planning and eventual retirement satisfaction and a negative correlation between the involuntariness of retirement on retirement satisfaction.

Finally, Panis (2004) examines the 2000 wave of the HRS to examine the role of annuities and wealth on both retirement satisfaction and measures of depression. Again, the list of determinants is limited, but Panis finds that annuities from pensions increase retirement satisfaction and reduce the number of depression symptoms, while Social Security reliance (as measured by how much Social Security contributes to total income) has no statistically 
significant effect on either well-being measure. Panis, however, does not control for other sources of income or wealth or for the voluntariness of retirement.

\section{Data and Methodology}

Health and Retirement Study. The data for this study come from the Health and Retirement Study (HRS), started in 1992 as a nationally representative sample of the US 51 to 61 year old population who are reinterviewed every other year. To date, this panel contains public release data for 1992, 1994, 1996, 1998, and 2000. After 1995, the HRS was merged with the Assets and Health Dynamics of the Oldest Old (AHEAD) dataset, resulting in a potential dataset of over 18,000 individuals across all waves. After deleting observations who did not report being fully retired (the criterion for answering questions about retirement well-being) and others with missing values for at least one variable, the resulting datasets had sample sizes of 6,246 for the retirement satisfaction sample and 6,085 for the retirement comparison sample.

Dependent Variables. The two dependent variables come from the retirement section of the HRS. Namely if a person self reports as being fully retired in 2000, they are asked two questions regarding subjective well-being during retirement. The most direct question on retirement well-being is, "G136. All in all, would you say that your retirement has turned out to be very satisfying, moderately satisfying, or not at all satisfying?" Table 1 contains the tabulation of the answers to this retirement satisfaction question. Over 60 percent of retirees are very satisfied with their retirement, with another third considering their retirement moderately satisfying. Approximately eight percent are not satisfied with their retirement.

The second retirement well-being question is somewhat less direct, as it asks the respondent to compare retirement well-being to well-being just before retirement: "G137. Thinking about your retirement years compared to the years just before you retired, would you say the retirement years have been better, about the same, or not as good?" Again, Table 1 shows that a majority find that retirement is better than to the years just before retirement, where 32.9 percent find it about the same, and 16.9 percent experience lower well-being in retirement than before retirement. ${ }^{3}$

Independent Variables and Expected Effects on Subjective Well-being. Descriptive statistics of the independent variables are given in Table 2. There are two separate samples employed in the analysis to take advantage of as many observations as possible. Although there is a difference of 161 observations, the descriptive statistics of the two samples are very similar.

The first set of independent variables capture socio-demographic characteristics. The samples tend to be married, white, educated with a high school education or below, and slightly more likely to be female. The respondents are fairly evenly distributed with respect to age, although it is slightly skewed toward older individuals (due to the older AHEAD dataset). Although there are no strong priors regarding the effect of these socio-demographic characteristics on retirement satisfaction, if the process that determines retirement and job satisfaction are similar, women would have higher retirement satisfaction while those with

\footnotetext{
${ }^{3}$ These subjective well-being variables are obviously related as indicated by a correlation coefficient of 0.59 (statistically significant at the one percent level) between the two variables.
} 
higher educational qualifications would have lower satisfaction. There is no consistent evidence in the job satisfaction literature regarding the relationship between race (nonHispanic white, black, and other races) and Hispanic ethnicity and satisfaction, so their anticipated effect on retirement satisfaction is unknown. Given the U-shaped relationship between job satisfaction and age, we might expect a similar relationship with retirement satisfaction or possibly that they are in the upward sloping portion of the $\mathrm{U}$.

The next set of variables concerns pension, income and wealth information. Several variables capture the type of pension a retiree has. If retirees are risk adverse, then it is likely that those with defined contribution (DC) pensions might have lower retirement satisfaction than those with the more secure defined bene fit (DB) pensions. Of course, having any pension which will give some resources in retirement should increase well-being over those with no pension. ${ }^{4}$ Other variables give averages of pension (plus annuity), Social Security retirement, and earned income, as well as all other household income and net wealth of the household (each divided by 1000). Increases in these income and wealth variables, often used to measure economic wellbeing, are expected to increase subjective well-being.

The third set of variables capture other influences on well-being. There are two reasons why the voluntariness of retirement might influence retiree well-being. First, if individuals are forced to retire early, e.g. because of economic or health reasons, they may retire before they are financially or psychologically ready, which could lead to lower well-being compared to those who voluntarily retire. Second, those who are forced to retire may be actually unemployed. Previous research by Osberg (1993) and Chan and Stevens (2001) shows that nonworking older workers face more constraints reentering the labor market, meaning that some of the retired could be "discouraged workers," that is, people willing to work, but who decide to drop out of the labor force. Given that unemployment decreases life satisfaction as reviewed above, forced retirement would lead to lower retiree well-being.

Other variables such as health should influence the ability to enjoy the additional leisure time that retirement affords, and the sample shows that a large majority of this sample enjoys at least good health. Likewise access to health insurance, as enjoyed by over 88 percent of the sample, should increase well-being. If there is complementarity in leisure time between spouses (Maestas 2002), whether the spouse is retired may increase well-being of the respondent. ${ }^{5}$ Nearly two-thirds of the sample has a spouse that is either partially or fully retired. The working status of the respondent may also influence well-being. The direction of the effect is unclear, however. As the labor force status/life satisfaction research discussed above shows, individuals who work often have higher life satisfaction even after controlling for the extra income from working. On the other hand, if a retiree is forced to work because of a lack of income, there may be a negative effect of work on retirement well-being. In either case, there are relatively few (less than three percent) of the self-reported fully retired who are employed. ${ }^{6}$

\footnotetext{
${ }^{4}$ This is a similar argument to Panis (2004) who examined relative Social Security reliance.

${ }^{5}$ See Groot and van den Brink (2002) for a discussion of the other links between life satisfaction and marriage.

${ }^{6}$ The previous discussion identifies differences in what economists and people in general consider retirement. Economists define retirement as a withdrawal from the labor force, while individuals tend to consider it as a separation from a long standing or career job regardless of their present labor force status. Since this is the way that
} 
The last set of variables capture any regional differences in the subjective well-being of retirees. Most of the respondents tend to be located in the population centers of the East Coast or in the South Atlantic region, which includes the popular retirement state of Florida.

Methodology. Given the ordered nature of the dependent variables, a standard ordered probit estimation procedure is followed where the well-being measures are dependent variables and the independent variables are included as regressors (except for the excluded dummy variables noted in Table 2). To investigate whether there are differences in the factors that determine well-being across various subgroups in the data, the ordered probit regressions are often estimated for several subgroups. ${ }^{7}$

In addition to these ordered probit regressions, two other specifications were also estimated. The first alternative is motivated by the job satisfaction literature which has found that relative income influences job satisfaction. In the same vein, it may be that relative retirement income will influence retirement satisfaction. In order to control for this, consider the following regression equation:

$S_{i}=\beta_{0}+\beta_{1} X_{i}+\beta_{2} I_{i}+\varepsilon_{i}$

where for respondent $\mathrm{i}, \mathrm{S}_{\mathrm{i}}$ is the retirement satisfaction measure, $\mathrm{X}$ is the vector of covariates explained above, $\mathrm{I}_{\mathrm{i}}$ is an income measure, the betas are estimated coefficients, and $\varepsilon_{\mathrm{i}}$ is an error term. To determine if relative income is important, then the following linear regression equation can be estimated:

$I_{i}=\alpha_{0}+\alpha_{1} X_{i}+\alpha_{2} Z_{i}+\eta_{i}$

where $Z_{i}$ is a vector of covariates related to income, ${ }^{8}$ but not well-being, and the alphas are estimated coefficients. From this regression, income is predicted $\left(\hat{\mathrm{I}}_{\mathrm{i}}\right)$ for each respondent and then subtracted from actual income. This difference replaces actual income, $\mathrm{I}_{\mathrm{i}}$, as a covariate in the following job satisfaction equation:

$$
S_{i}=\beta_{0}+\beta_{1} X_{i}+\beta_{2}^{\prime}\left(I_{i}-\hat{I}_{i}\right)+\varepsilon_{i}
$$

As the difference between actual and predicted income becomes greater, subjective well-being should increase (that is $\beta_{2}^{\prime}>0$ ), since the respondent is receiving income greater than what would

the HRS interprets retirement, I will also use this definition. Most of the regression results below continue to hold if I consider only those who fit the economist's definition and are not currently employed.

${ }^{7}$ Alternative specifications including ordered logit and binomial probit estimations yielded similar results to the ordered probit. These results are available from the author.

${ }^{8}$ In the results presented below, the variables in the $Z_{i}$ vector are the number of people in the household. 
be predicted for his/her characteristics. ${ }^{9}$ This methodology is replicated for each retirement income measure - pension, Social Security retirement, earned, and other household income.

A second estimation alternative is motivated by the very specific subsample of the HRS used, namely those who consider themselves fully retired. Because the designation of full retirement is a choice by the respondent, these individuals might be different in nonrandom ways from the rest of the population. This sample selection problem could lead to biases in the estimates of the standard ordered probit regressions discussed above. To attempt to correct for this, I collapse the well-being measure into a dummy variable indicating whether or not individuals are very satisfied with their retirement (or feel that their retirement is much better than the time before retirement for the other well-being measure). With these newly defined dependent variables and another variable that indicates whether a person is fully retired or not, the estimation procedure becomes a bivariate probit with sample selection model (van de Ven and van Pragg, 1981). ${ }^{10}$

\section{Results}

Basic Results. The first column of Table 3 contains the estimated coefficients of the ordered probit regression for the retirement satisfaction measure of retiree well-being. As in the job satisfaction literature, male retirees have lower retirement satisfaction than female retirees, ceteris paribus, although the marginal effect is small, with males being 3.5 percent less likely of being in the highest retirement satisfaction category. ${ }^{11}$ Being married increases the probability of being in the highest category by 6.2 percent. There are no statistically significant effects by race or education, however. The results show that older retirees have higher retirement satisfaction than those who are under 62 years old, with the marginal effects of the 70 to 74 and $75+$ age groups being 13.5 and 18.0 percent higher for being in the highest satisfaction category compared to those who are under 62 years old. This is consistent with the "right hand" portion of the familiar U-shaped age-satisfaction relationship.

\footnotetext{
${ }^{9}$ This is admittedly a strong assumption, since I have no information on to whom retirees might compare their income. Since I lack this information, I use the methodology from the job satisfaction literature. One alternative, however, would be to compare retirement income to preretirement income. Unfortunately, given that many individuals in this sample retired before 1992, I have no information on preretirement income, reducing the sample considerably.

${ }^{10}$ This method requires including variables that influence the selection equation but do not influence the well-being regressions. In the results presented below, these variables include number of individuals in the household and region of birth (one of the nine US regions or born outside of the US).

${ }^{11}$ The coefficients from the ordered probit estimation procedure recorded in Tables 3 and 4 are not marginal effects. Using the estimated cut points, one can calculate the probability of being in each satisfaction (or comparison) category. To calculate the marginal effects mentioned in the text, I evaluate these probabilities at the means of all the variables except the one that is being changed. In addition, to reduce the number of reported results, I report just the marginal effects of being in the highest satisfaction (or comparison) category. The predicted probability of being in the highest retirement satisfaction category is 61.6 percent while it is 49.8 percent (which are close to the sample means) for being in the highest retirement comparison category. Of course, given the nonlinearity of the cumulative normal distribution, the marginal effects may be larger for the probability of being in other categories. These results are available from the author.
} 
The next set of variables measure any effects of pension characteristics, income sources and net household wealth. The type of pension plays an important role, as it does in the job satisfaction literature. Having no pension decreases the probability of being in the highest satisfaction category by 7.3 percent compared to those with only DB pensions. Interestingly, having just a DC pension reduces the probability of being in the highest job satisfaction category by 9.8 percent, possibly showing the effects of the relatively high personal risk run by those with DC plans. This negative effect on retirement satisfaction is seemingly mollified when DC plans are combined with DB plans since there is no statistically significant difference with those with just DB plans.

As expected income and wealth tend to increase retirement satisfaction. Pension, Social Security, and other household income all increase retirement satisfaction, while there is a U shaped relationship between satisfaction and wealth. Only extra income from earnings does not increase satisfaction. In all cases the marginal effects are relatively small with an increase in income by $\$ 1000$ only contributing a less than one percent increase in the probability in being in the highest satisfaction category.

Many of the rest of the variables have statistically significant influences on retirement satisfaction. As found previously (Shultz et al. 1998 and Elder and Rudolph 1999), compared to those who voluntarily retired, those who were forced or partially forced to retire had lower retirement satisfaction. This may reflect that retirement happened before they expected it. ${ }^{12}$ The marginal effects for these variables are relatively large. Those who are forced to retire are 29.7 percent less likely to report being in the highest satisfaction category (nearly half of the 61.6 percent predicted probability of being in that category) while those who were partially forced to retire are 20.1 percent less likely to be in that category. ${ }^{13}$ Likewise, having less than very good health leads to lower retirement satisfaction compared to those in excellent health (by magnitudes of 20.6 to 42.8 percent for the bottom three health groups), which is expected if health is a complement to leisure time in utility. Even holding earned income constant, working increases retirement satisfaction, although having a spouse working reduces retirement satisfaction, indicating there may be some complementarity in leisure. Interestingly, having nongovernment health insurance or a combination of government and private health insurance increases satisfaction (by 14.5 and 6.7 percent respectively for the highest satisfaction category) compared to those with just government supplied health insurance (e.g. Medicare, Medicaid, etc). There is no statistically significant difference between having these government health insurance sources and no health insurance.

The first column of Table 4 records the results of the ordered probit estimation of the retirement comparison measure of well-being. In general, the results are similar to the satisfaction results, although there are important differences. Being married makes it more likely

\footnotetext{
${ }^{12}$ On a related issue, Dwyer and $\mathrm{Hu}$ (2000) examine the role of retirement expectations, unexpected health shocks and changes in the decision to retire.

${ }^{13}$ To get a sense of the relative magnitudes of these involuntary retirement variables, using the retirement satisfaction ordered probit coefficient estimates, it would take an increase of more than $\$ 110,000(\$ 73,000)$ of pension income to wipe out the negative effect of being forced (partially forced) to retire. On the other hand because of the different relative (subjective) value of income, it would take an increase of more than $\$ 574,000$ $(\$ 381,000)$ of other household income to overcome the negative effects of involuntary retirement.
} 
that a respondent feels that retirement is better than pre-retirement years, although gender, education, and race play no statistically significant effect. Those who are 65 or older report higher well-being. Unlike retirement satisfaction, the pension characteristics (with the exception of having no pension), income and wealth measures are not related to this measure of well-being. As before, the voluntariness of retirement strongly influences well-being, although the magnitudes of the marginal effects are smaller than before (23.2 and 11.6 percent less likely to be in the top comparison category for the forced and partially forced, respectively). Selfreported health has a similar pattern as above. A working respondent and those with nongovernmental health insurance experience higher well-being.

Estimates by gender and race/ethnicity. The other columns of Table 3 and Table 4 record the results of the ordered probit estimations by gender and white/nonwhite status for retirement satisfaction and comparisons, respectively. Examining retirement satisfaction across genders in Table 3 first, there are few differences between genders. The most obvious differences are that pension characteristics, income and wealth are statistically significant determinants of retirement satisfaction for men but not women. In addition, the fact that their spouse works decreases male retirement satisfaction but not female satisfaction.

For the retirement comparison regressions in Table 4, Hispanic men, but not women, show significantly lower well-being than whites. Females who are working tend to have higher well-being, compared to nonworking women, while this is not the case for working men. The effects of age, involuntary retirement, health, and health insurance source are all similar across groups.

The final two columns of these tables contain results for nonwhite and white retirees. Table 3 shows that the male, married, pension characteristics, income and wealth influences are driven by white retirees. Age, involuntary retirement, and health all have similar influences on retirement satisfaction. Interestingly, the retirement comparison results in Table 4 show other differences. There are male differences between races/ethnicities, with nonwhite males having lower well-being compared to women, while white males have higher levels of well-being. Marital status influences white well-being more, as does (to a lesser extent) pension characteristics, health, and health insurance. On the other hand income sources influence nonwhite well-being more than white well-being.

Are the "voluntarily" retired different? One of the most consistent significant determinants of well-being is with the "voluntariness" of retirement. Therefore, the next set of results disaggregate by this variable. Since there were relatively few individuals who reported partially forced/partially wanting to retire, all of these individuals are identified as being "forced" to retire. The results from these estimations are found in Table 5.

Gender plays an important role in the retirement satisfaction (first two columns) for the voluntarily retired, but there are no differences by gender for the involuntarily retired. On the other hand, pension characteristics play a larger role for the involuntarily retired, likely due to the fact that they were not able to accumulate their expected pension account balances. Net worth also influences satisfaction more among this group, possibly because of the reliance on 
other sources of wealth to fund retirement consumption. Health and health insurance influence both groups in similar directions.

For the retirement comparison measure of well-being, we see even more differences. Now there is no gender difference for the voluntarily retired, although males have higher wellbeing for the involuntarily retired. Age is a much stronger determinant for the involuntarily retired. A more diversified pension bala nce between DB and DC plans positively influence wellbeing for the involuntarily retired, while having no pension is negatively associated with wellbeing amongst the voluntarily retired. Income plays only a marginal role for either group, and health and health insurance sources have generally similar effects. ${ }^{14}$

Income and well-being. One of the interesting results from these estimations is that increased income has a positive, but small, impact on well-being. However, it may not be that absolute levels of income are all that important. As mentioned above, earlier research on job satisfaction has found that relative income may be as important as absolute income in determining job satisfaction. Therefore, in this section, I analyze relative income measures to see if comparison, rather than absolute, income influences retiree well-being.

Table 6 contains selected results from four different specifications of the influence of relative earnings on well-being, reporting the marginal effect on the probability of being in the highest respective well-being category. ${ }^{15}$ In the first two specifications, I use a measure of total household income. In Specification 1, a simple difference between actual and predicted total household income is included as a regressor. As Table 6 shows, as actual income increases above predicted income, there is a statistically significant, although small, increase in the probability of being in the highest satisfaction category, although there is no significant impact on the retirement comparison measure. An alternative to including the difference is creating a dummy variable indicating when an individual has greater than predicted income, which is what is done in Specification 2. Both coefficients on this indicator variable are statistically significant and positive, although the marginal effect on retirement satisfaction is greater than the effect on retirement comparison (a 6.8 percent compared to a 3.5 percent increase).

The next two specifications decompose income into four component parts - pension, Social Security retirement, earned, and other household income. Using the method described above and the regression coefficients found in Appendix Table 1, differences between actual and predicted levels of income are included as regressors in Specification 3. ${ }^{16}$ As before, differences in actual and predicted pension, Social Security and other household income are associated with

\footnotetext{
${ }^{14}$ Unfortunately, there is no information in the HRS to say why individuals are involuntarily retired, which might shed further light on this issue.

15 Appendix Table 1 contains the OLS results of the various income regressions. Since the results are relatively standard, I will not comment on them here. The effect of the other covariates on well-being in Table 6 are similar to the previous results in Tables 3 and 4. Full results are available from the author.

${ }^{16}$ For those who are not yet eligible for Social Security retirement benefits, their Social Security income difference is zero. Since this is a relatively large portion of the sample, Specifications 3 and 4 were also estimated for those who are 62 years old or older. The results are not significantly different than those reported in Table 6.
} 
higher retirement satisfaction but are not related to the retirement comparison measure (perhaps because the relative income amounts are already built into the comparison between pre and post retirement living). A thousand dollar increase in the actual-predicted difference in pension or Social Security income influences the probability more at the margin than a thousand dollar increase in other household income. Replacing the actual difference with an indicator variable, Specification 4, results in similar marginal effects for the retirement satisfaction estimates and statistically significant increases in retirement comparison well-being for pension and other household income that is above the predicted level.

Controlling for Sample Selection. The last set of regressions involve controlling for the fact that the sample of the fully retired may be different in nonrandom ways from the rest of the HRS sample. Using the bivariate probit model with sample selection referenced above, I can see if sample selection is influencing the results found above. Table 7 contains the results of this exercise, reporting the marginal effects of the estimated coefficients. ${ }^{17}$

The first column for each well-being measure reports results from a standard probit regression without a selection correction to make sure that the relationships found using the ordered probit are repeated using a probit. By and large, the probit results conform to the results found above. The primary difference is that gender is not important in the retirement satisfaction probit in Table 7, and marital status and increased education now positively influence the retirement comparison probit in Table 7, where they were not significant in the ordered probit results reported in Table 4.

The second columns for these well-being measures contain the results of the sample selection corrected probits. For retirement satisfaction, the same set of variables continue to be important with similar magnitudes for the marginal effects, indicating that sample selection does not seem to be an important issue for this group. Indeed, the $?^{2}$ test for independence shows that we cannot reject independence, indicating a lack of support for sample selection. Most of the same pattern is repeated for retirement comparison, with similar variables being statistically significant across the two econometric methods. The difference here, however, is that the size of the marginal effects tends to grow (in absolute value) when moving to the sample selection results. Therefore the effect of controlling for sample selection (here the ${ }^{2}$ test for independence across equations fails at the 5 percent level) makes the significant coefficients have a larger relative impact on the well-being.

\section{Conclusions}

Understanding the factors that determine well-being of retirees is an important econo mic and policy topic. Although most previous studies examine only economic well-being, this study examines a broader measure of well-being to examine if other determinants than economic wellbeing measures are important. The results show that while economic well-being (as measured by income and wealth) does increase overall well-being, the effect is relatively small. In addition, these economic measures are more influential for men compared to women

\footnotetext{
${ }^{17}$ Appendix Table 2 has the results from the fully retired/not fully retired selection regression.
} 
On the other hand, two other factors stand out as having a more important effect on wellbeing. The first is the reason for retirement. If individuals say that they voluntarily retired, they express much higher levels of well-being compared to those who did not voluntarily retire. It is likely that if they retired before they had expected to, financial or psychological preparations for retirement may not have been fully completed, leading to lower well-being in retirement. Indeed, the effects of involuntary retirement may actually be greater than reported here since the involuntary retired also have lower levels of pension, Social Security, earned, and other household income which would decrease satisfaction even further. The second major factor is health. Unsurprisingly, those with poor health also experience dramatically lower levels of wellbeing. Although neither of these factors are controllable from a policy point of view, they do indicate areas where more research could be done to help assure higher levels of well-being for retirees. 


\section{References}

Andrews, Emily S. (1993) "Gaps in Retirement Income Adequacy," in The Future of Pensions in the United States, ed. by Richard Schmitt, Philadelphia: Pension Research Council and University of Pennsylvania Press: 1-31.

Bahizi, Pierre. 2003. "Retirement Expenditures for Whites, Blacks, and Persons of Hispanic Origin." Monthly Labor Review 126(6): 20-22.

Blanchflower, David and Andrew Oswald. 1999. "Well-Being, Insecurity and the Decline of American Job Satisfaction." Working Paper.

Chan, Sewin and Ann Huff Stevens. 2001. "Job Loss and Employment Patterns of Older Workers.” Journal of Labor Economics 19(2): 484-521.

Charles, Kerwin K. 2002. "Is Retirement Depressing? Labor Force Inactivity and Psychological Well-Being in Later Life.” NBER Working Paper, \#9033.

Clark, Andrew E., Y. Georgellis, and P. Sanfey. 1998. "Job Satisfaction, Wage Changes and Quits: Evidence from Germany.” Research in Labor Economics 17: 95-122.

Clark, Andrew E. and Andrew J. Oswald. 1994. "Unhappiness and Unemployment." The Economic Journal 104: 648-59.

Clark, Andrew E. and Andrew J. Oswald. 1996. "Satisfaction and Comparison Income." Journal of Public Economics 61: 359-81.

Dwyer, Debra Sabatini and Jianting Hu. 2000. "Retirement Expectations and Realizations: The Role of Health Shocks and Economic Factors.” In Olivia S. Mitchell, P. Brett Hammond, and Anna M. Rappaport eds. Forecasting Retirement Needs and Retirement Wealth. Philadelphia: University of Pennsylvania Press: 274-87.

Elder, Harold W. and Patricia M. Rudolph. 1999. "Does Retirement Planning Affect the Level of Retirement Satisfaction?” Financial Services Review 8: 117-27.

Frey, Bruno S. and Alois Stutzer. 2002a. Happiness and Economics: How the Economy and Institutions Affect Well-being, Princeton, NJ: Oxford University Press.

Frey, Bruno S. and Alois Stutzer. 2002b. "What Can Economists Learn from Happiness Research?" Journal of Economic Literature 40(2): 402-35.

Gerlach, Knut and Gesine Stephan. 1996. "A Paper on Unhappiness and Unemployment in Germany." Economics Letters 52(3): 325-30. 
Groot, Wim and Henriëtte Maassen van den Brink. 2002. "Age and Education Differences in Marriages and Their Effects on Life Satisfaction." Journal of Happiness Studies 3: 15365 .

Hamermesh, Daniel S. 2001. "The Changing Distribution of Job Satisfaction." The Journal of Human Resources 36: 1-30.

Haveman, Robert, Karen Holden, Kathryn Wilson, and Barbara Wolfe. 2003. "Social Security, Age of Retirement, and Economic Well-being: Intertemporal and Demographic Patterns among Retired-Worker Beneficiaries." Demography 40(2): 369-94.

Iaffaldano, Michelle T. and Paul M. Muchinsky. 1985. "Job Satisfaction and Job Performance: A Meta-Analysis." Psychology Bulletin 97(2): 251-73.

Levine, Philip B., Olivia S. Mitchell, and James F. Moore. 2000. "Women on the Verge of Retirement: Predictors of Retiree Wellbeing.” In Olivia S. Mitchell, P. Brett Hammond, and Anna M. Rappaport, eds. Forecasting Retirement Needs and Retirement Wealth. Philadelphia: University of Pennsylvania Press, 167-95.

Luchak, Andrew A. and Ian R. Gellatly. 2002. "How Pension Accrual Affects Job Satisfaction." Journal of Labor Research 23(1): 145-62.

Maestas, Nicole A. 2002. Planning for Widowhood? Joint Retirement and the Allocation of Pension Income by Older Couples, Dissertation, UC-Berkeley.

Morisha, Motohiro. 1986. "Job Satisfaction and Desire to Quit: Differences in the Determinants of Two Responses." In Proceedings of the $38^{\text {th }}$ Annual Meeting, Madison, WI: Industrial Relations Research Association: 80-91.

OECD. 2001. Ageing and Income: Financial Resources and Retirement in 9 OECD Countries, Paris: Organisation for Economic Co-operation and Development.

Osberg, Lars. 1993. "Is It Retirement or Unemployment? Induced 'Retirement' and Constrained Labour Supply Among Older Workers.” Applied Economics 25: 505-19.

Ostroff, C. 1992. "The Relationship between Satisfaction, Attitudes and Performance: An Organizational Level Analysis.” Journal of Applied Psychology 77: 963-74.

Panis, Constantijn W. A. 2004. "Annuities and Retirement Well-Being." In Olivia S. Mitchell and Stephen P. Utkus, eds. Pension Design and Structure: New Lessons from Behavioral Finance. Oxford: Oxford University Press, forthcoming.

Radner, Daniel B. (1998) "The Retirement Prospects of the Baby Boom Generation," Social Security Bulletin, 61(1): 3-19. 
Rogers, J., K. Clow, and T. Kash. 1994. "Increasing Job Satisfaction of Service Personnel." Journal of Service Management 8, 14-26.

Shultz, Kenneth S., Kelly R. Morton, and Joelle R. Weckerle. 1998. "The Influence of Push and Pull Factors on Voluntary and Involuntary Early Retirees' Retirement Decision and Adjustment." Journal of Vocational Behavior 53: 45-57.

Theodossiou, Ioannis. 1998. "The Effects of Low-pay and Unemployment on Psychological Well-being: A Logistic Approach.” Journal of Health Economics 17: 85-104.

van de Ven, W.P.M.M. and B.M.S. van Pragg. 1981. "The Demand for Deductibles in Private Health Insurance: A Probit Model with Sample Selection." Journal of Econometrics 17: $229-52$.

van Praag, B.M.S., P. Frijters, and A. Ferrer-i-Carbonell. 2002. "The Anatomy of Subjective Well-being." Journal of Economic Behavior \& Organization 51: 29-49.

Wiatrowski, William. 1993. "Factors Affecting Retirement Income," Monthly Labor Review 116(3): 25-35.

Winkelman, Liliana and Rainer Winkelman. 1998. "Why Are the Unemployed So Unhappy? Evidence from Panel Data." Economica 65(257): 1-15.

Wottiez, Isolde and Jules Theeuwes. 1998. "Well-being and Labor Market Status." In Stephen P. Jenkins, Arie Kapteyn, and Barnard M.S. van Praag, eds. The Distribution of Welfare and Household Production: International Perspectives. Cambridge: Cambridge University Press: 211-30. 
Table 1. Tabulations of Subjective Retirement Well-being Questions

Satisfaction with Retirement

\begin{tabular}{|c|c|c|c|}
\hline Not at all satisfying $(=1)$ & $\begin{array}{c}468 \\
(7.5 \%)\end{array}$ & Not as $\operatorname{good}(=1)$ & $\begin{array}{c}1,026 \\
(16.9 \%)\end{array}$ \\
\hline Moderately satisfying $(=2)$ & $\begin{array}{c}2,023 \\
(32.4 \%)\end{array}$ & About the same $(=2)$ & $\begin{array}{c}2,000 \\
(32.9 \%)\end{array}$ \\
\hline Very satisfying $(=3)$ & $\begin{array}{c}3,755 \\
(60.1 \%)\end{array}$ & Better $(=3)$ & $\begin{array}{c}3,059 \\
(50.3 \%)\end{array}$ \\
\hline
\end{tabular}

Notes: Figures are numbers of responses (and percentages) to the two retirement well-being questions for the data sample used from the 2000 Wave of the HRS. 
Table 2. Descriptive Statistics of Dependent and Independent Variables by Well-being Measure

\begin{tabular}{|c|c|c|}
\hline & Retirement Satisfaction & Retirement Comparison \\
\hline \multirow[t]{2}{*}{ Well-Being measure } & 2.523 & 2.333 \\
\hline & $(0.637)$ & $(0.752)$ \\
\hline Male & 0.497 & 0.496 \\
\hline Married & 0.590 & 0.591 \\
\hline White non-Hispanic (excl) & 0.836 & 0.837 \\
\hline Black non-Hispanic & 0.097 & 0.095 \\
\hline Other race non-Hispanic & 0.021 & 0.021 \\
\hline Hispanic & 0.047 & 0.047 \\
\hline Below HS degree (excl) & 0.287 & 0.289 \\
\hline HS degree & 0.345 & 0.344 \\
\hline Some college & 0.186 & 0.187 \\
\hline College or postgrad & 0.181 & 0.181 \\
\hline Age under 62 (excl) & 0.162 & 0.158 \\
\hline Age 62-64 & 0.057 & 0.054 \\
\hline Age $65-69$ & 0.217 & 0.215 \\
\hline Age $70-74$ & 0.218 & 0.222 \\
\hline Age $75+$ & 0.346 & 0.351 \\
\hline DB pension only (excl) & 0.165 & 0.165 \\
\hline DC pension only & 0.086 & 0.085 \\
\hline DB and DC pension & 0.132 & 0.127 \\
\hline Undetermined pension & 0.011 & 0.010 \\
\hline No pension & 0.606 & 0.613 \\
\hline \multirow[t]{2}{*}{ Pension + annuity income/1000 } & 6.758 & 6.757 \\
\hline & $(14.556)$ & $(14.588)$ \\
\hline \multirow[t]{2}{*}{ Social Security retirement income/1000 } & 8.005 & 8.036 \\
\hline & $(4.877)$ & $(4.848)$ \\
\hline \multirow[t]{2}{*}{ Earnings/1000 } & 1.902 & 1.349 \\
\hline & $(9.864)$ & $(8.163)$ \\
\hline \multirow[t]{2}{*}{ Other household income/1000 } & 22.947 & 23.039 \\
\hline & $(45.675)$ & $(45.571)$ \\
\hline \multirow[t]{2}{*}{ Net Household Wealth/1000 } & 382.863 & 383.110 \\
\hline & $(796.898)$ & (794.209) \\
\hline Wanted to retired (excluded) & 0.632 & 0.634 \\
\hline Forced to retire & 0.284 & 0.283 \\
\hline Partly wanted, forced & 0.084 & 0.083 \\
\hline Excellent self-reported health (excluded) & 0.104 & 0.103 \\
\hline Very good health & 0.278 & 0.276 \\
\hline Good health & 0.303 & 0.304 \\
\hline Fair health & 0.214 & 0.214 \\
\hline Poor health & 0.102 & 0.103 \\
\hline Respondent has govt health ins. Only (excl) & 0.331 & 0.333 \\
\hline Resp. has other health ins. only & 0.161 & 0.155 \\
\hline Resp. has govt and other ins. & 0.478 & 0.485 \\
\hline Resp. has no health ins. & 0.030 & 0.027 \\
\hline Spouse working & 0.143 & 0.141 \\
\hline Respondent is currently working & 0.036 & 0.037 \\
\hline \# Observations & 6246 & 6085 \\
\hline
\end{tabular}

Notes: Numbers in parentheses are standard deviations of continuous variables. (Excl) indicates that variable is excluded in multivariate regressions. All statistics are weighted by the 2000 Wave respondent sample weights. 
Table 3. Ordered Probit Regressions of Retirement Satisfaction Measure of Well-being

\begin{tabular}{|c|c|c|c|c|c|}
\hline & Full Sample & Female & Male & Nonwhite & White \\
\hline \multicolumn{6}{|l|}{ Demographic Characteristics } \\
\hline \multirow[t]{2}{*}{ Male } & $-0.092 * *$ & & & -0.084 & $-0.098 * *$ \\
\hline & -2.14 & & & -0.95 & -2.00 \\
\hline \multirow[t]{2}{*}{ Married } & $0.161 * * *$ & $0.146 * *$ & $0.174 * * *$ & 0.041 & $0.187 * * *$ \\
\hline & 3.67 & 2.30 & 2.67 & 0.43 & 3.76 \\
\hline \multirow[t]{2}{*}{ Black } & -0.013 & 0.016 & -0.045 & -0.038 & \\
\hline & -0.23 & 0.22 & -0.49 & -0.35 & \\
\hline \multirow[t]{2}{*}{ Other race } & -0.140 & 0.008 & $-0.270 *$ & -0.163 & \\
\hline & -1.17 & 0.04 & -1.77 & -1.06 & \\
\hline \multirow[t]{2}{*}{ Hispanic } & -0.011 & -0.054 & 0.013 & & \\
\hline & -0.13 & -0.44 & 0.11 & & \\
\hline \multirow[t]{2}{*}{ HS degree } & 0.029 & 0.026 & 0.032 & 0.091 & 0.010 \\
\hline & 0.63 & 0.41 & 0.48 & 0.92 & 0.19 \\
\hline \multirow[t]{2}{*}{ Some college } & -0.022 & 0.034 & -0.084 & 0.090 & -0.042 \\
\hline & -0.40 & 0.43 & -1.05 & 0.65 & -0.68 \\
\hline \multirow[t]{2}{*}{ College or postgrad } & 0.036 & 0.110 & -0.033 & -0.102 & 0.043 \\
\hline & 0.54 & 1.14 & -0.37 & -0.69 & 0.57 \\
\hline \multirow[t]{2}{*}{ Age $62-64$} & 0.108 & $0.199 *$ & 0.032 & 0.126 & 0.114 \\
\hline & 1.31 & 1.70 & 0.27 & 0.83 & 1.17 \\
\hline \multirow[t]{2}{*}{ Age 65-69 } & $0.217 * * *$ & $0.227 * *$ & $0.232 * *$ & $0.352 * *$ & $0.180 * *$ \\
\hline & 2.81 & 2.10 & 2.09 & 2.41 & 2.00 \\
\hline \multirow{2}{*}{ Age 70-74 } & $0.368 * * *$ & $0.452 * * *$ & $0.304 * *$ & $0.493 * * *$ & $0.332 * * *$ \\
\hline & 4.18 & 3.67 & 2.42 & 2.82 & 3.23 \\
\hline \multirow[t]{2}{*}{ Age $75+$} & $0.489 * * *$ & $0.547 * * *$ & $0.447 * * *$ & $0.649 * * *$ & $0.446 * * *$ \\
\hline & 5.57 & 4.53 & 3.48 & 3.74 & 4.36 \\
\hline \multicolumn{6}{|c|}{ Pension Chara cteristics, Income and Wealth Variables } \\
\hline \multirow[t]{2}{*}{ DC pension only } & $-0.250 * * *$ & $-0.206^{*}$ & $-0.278 * * *$ & 0.103 & $-0.314 * * *$ \\
\hline & -3.19 & -1.69 & -2.79 & 0.67 & -3.59 \\
\hline \multirow[t]{2}{*}{ Both DB and DC pension } & 0.028 & 0.104 & -0.014 & 0.149 & $5.6 \mathrm{E}-4$ \\
\hline & 0.41 & 0.96 & -0.16 & 1.07 & 0.01 \\
\hline \multirow[t]{2}{*}{ Undetermined pension } & -0.151 & -0.070 & -0.194 & 0.231 & -0.262 \\
\hline & -0.90 & -0.22 & -1.02 & 0.58 & -1.54 \\
\hline \multirow[t]{2}{*}{ No pension } & $-0.193 * * *$ & -0.124 & $-0.225 * * *$ & 0.031 & $-0.234 * * *$ \\
\hline & -3.15 & -1.32 & -2.75 & 0.24 & -3.37 \\
\hline \multirow[t]{2}{*}{ Pension income/1000 } & $0.007 * * *$ & $0.007 *$ & $0.007 * * *$ & 0.009 & $0.007 * * *$ \\
\hline & 3.09 & 1.77 & 2.61 & 1.57 & 2.77 \\
\hline \multirow[t]{2}{*}{ Soc Sec ret income/1000 } & $0.008 *$ & 0.003 & $0.011 *$ & $5.1 \mathrm{E}-5$ & $0.010 * *$ \\
\hline & 1.86 & 0.37 & 1.83 & 0.01 & 2.05 \\
\hline \multirow[t]{2}{*}{ Earnings/1000 } & -0.003 & $-9.4 \mathrm{E}-4$ & -0.003 & $3.6 \mathrm{E}-4$ & -0.004 \\
\hline & -1.36 & -0.20 & -1.43 & 0.10 & -1.56 \\
\hline \multirow[t]{2}{*}{ Other $\mathrm{HH}$ income/1000 } & $1.3 \mathrm{E}-3 * *$ & $1.3 \mathrm{E}-3$ & 0.002 & 0.002 & $1.3 \mathrm{E}-3 * *$ \\
\hline & 2.12 & 1.49 & 1.55 & 0.63 & 2.00 \\
\hline \multirow[t]{2}{*}{ Household Net Worth/1000 } & $1.6 \mathrm{E}-4 * * *$ & $1.7 \mathrm{E}-4$ & $1.7 \mathrm{E}-4 * *$ & $4.7 \mathrm{E}-4$ & $1.4 \mathrm{E}-4 * *$ \\
\hline & 2.64 & 1.65 & 2.21 & 1.46 & 2.33 \\
\hline Net Worth/1000 Squared & $-1.2 \mathrm{E}-8 * *$ & $-1.6 \mathrm{E}-8^{*}$ & $-1.1 \mathrm{E}-8^{*}$ & $-7.3 \mathrm{E}-8$ & $-1.0 \mathrm{E}-8 * *$ \\
\hline & -2.41 & -1.86 & -1.73 & -1.08 & -2.07 \\
\hline
\end{tabular}


Table 3 continued

\begin{tabular}{|c|c|c|c|c|c|}
\hline \multicolumn{6}{|l|}{ Other Variables } \\
\hline \multirow[t]{2}{*}{ Forced to retire } & $-0.769 * * *$ & $-0.826 * * *$ & $-0.711 * * *$ & $-0.774 * * *$ & $-0.771 * * *$ \\
\hline & -18.42 & -14.49 & -11.63 & -9.40 & -16.16 \\
\hline \multirow[t]{2}{*}{ Partly wanted, forced ret. } & $-0.512 * * *$ & $-0.610 * * *$ & $-0.416 * * *$ & $-0.430 * * *$ & $-0.535 * * *$ \\
\hline & -8.16 & -6.87 & -4.61 & -3.18 & -7.63 \\
\hline \multirow[t]{2}{*}{ Very good health } & $-0.188 * *$ & $-0.244 * *$ & -0.138 & -0.227 & $-0.185 * *$ \\
\hline & -2.41 & -2.34 & -1.18 & -1.10 & -2.19 \\
\hline \multirow[t]{2}{*}{ Good health } & $-0.532 * * *$ & $-0.575 * * *$ & $-0.501 * * *$ & $-0.338 *$ & $-0.567 * * *$ \\
\hline & -7.01 & -5.59 & -4.53 & -1.76 & -6.86 \\
\hline \multirow[t]{2}{*}{ Fair health } & $-0.746 * * *$ & $-0.799 * * *$ & $-0.708 * * *$ & $-0.470 * *$ & $-0.809 * * *$ \\
\hline & -9.31 & -7.33 & -6.04 & -2.43 & -9.17 \\
\hline \multirow[t]{2}{*}{ Poor health } & $-1.145^{* * *}$ & $-1.224 * * *$ & $-1.087 * * *$ & $-1.006 * * *$ & $-1.161 * * *$ \\
\hline & -12.44 & -9.67 & -8.09 & -4.68 & -11.25 \\
\hline \multirow[t]{2}{*}{ Respondent working } & 0.170 & 0.185 & 0.178 & 0.300 & 0.145 \\
\hline & 1.61 & 1.15 & 1.28 & 1.18 & 1.24 \\
\hline \multirow[t]{2}{*}{ Spouse working } & $-0.142 * *$ & -0.138 & $-0.147 * *$ & -0.156 & $-0.121^{*}$ \\
\hline & -2.49 & -1.46 & -2.03 & -1.19 & -1.90 \\
\hline \multirow[t]{2}{*}{ Has other health ins. only } & $0.400 * * *$ & $0.376 * * *$ & $0.446 * * *$ & $0.575 * * *$ & $0.357 * * *$ \\
\hline & 4.80 & 3.20 & 3.73 & 3.05 & 3.84 \\
\hline \multirow[t]{2}{*}{ Has both govt and other health ins. } & $0.177 * * *$ & $0.180 * * *$ & $0.172 * * *$ & 0.128 & $0.190 * * *$ \\
\hline & 4.14 & 3.02 & 2.79 & 1.23 & 3.99 \\
\hline \multirow[t]{2}{*}{ No health insurance } & 0.061 & 0.107 & 0.033 & 0.237 & -0.007 \\
\hline & 0.48 & 0.69 & 0.18 & 1.28 & -0.05 \\
\hline Chi-Squared & $1291.91 * * *$ & $715.18 * * *$ & $645.73 * * *$ & $249.96 * * *$ & $1014.10 * * *$ \\
\hline \# of Observations & 6246 & 3109 & 3137 & 1369 & 4877 \\
\hline
\end{tabular}


Table 4. Ordered Probit Regressions of Retirement Comparison Measure of Well-being

\begin{tabular}{|c|c|c|c|c|c|}
\hline & Full Sample & Female & Male & Nonwhite & White \\
\hline \multicolumn{6}{|l|}{ Demographic Variables } \\
\hline \multirow[t]{2}{*}{ Male } & 0.055 & & & $-0.149 *$ & $0.100 * *$ \\
\hline & 1.39 & & & -1.81 & 2.23 \\
\hline \multirow[t]{2}{*}{ Married } & $0.149 * * *$ & $0.165 * * *$ & $0.168 * * *$ & -0.098 & $0.183 * * *$ \\
\hline & 3.64 & 2.78 & 2.76 & -1.09 & 3.97 \\
\hline \multirow[t]{2}{*}{ Black } & -0.005 & 0.084 & -0.111 & 0.051 & \\
\hline & -0.09 & 1.13 & -1.24 & 0.10 & \\
\hline \multirow[t]{2}{*}{ Other race } & 0.067 & 0.226 & -0.072 & 0.113 & \\
\hline & 0.60 & 1.48 & -0.43 & 0.14 & \\
\hline \multirow[t]{2}{*}{ Hispanic } & -0.116 & 0.067 & $-0.264 * *$ & & \\
\hline & -1.45 & 0.54 & -2.52 & & \\
\hline \multirow[t]{2}{*}{ HS degree } & 0.040 & 0.050 & 0.016 & 0.059 & 0.015 \\
\hline & 0.93 & 0.81 & 0.25 & 0.60 & 0.31 \\
\hline \multirow[t]{2}{*}{ Some college } & 0.055 & 0.068 & 0.044 & 0.091 & 0.032 \\
\hline & 1.04 & 0.93 & 0.56 & 0.67 & 0.55 \\
\hline \multirow[t]{2}{*}{ College or postgrad } & 0.091 & 0.085 & 0.077 & 0.117 & 0.058 \\
\hline & 1.49 & 0.96 & 0.92 & 0.74 & 0.87 \\
\hline \multirow[t]{2}{*}{ Age $62-64$} & 0.102 & $0.203^{*}$ & -0.007 & 0.111 & 0.120 \\
\hline & 1.17 & 1.78 & -0.05 & 0.71 & 1.18 \\
\hline \multirow[t]{2}{*}{ Age 65-69 } & $0.292 * * *$ & $0.337 * * *$ & $0.258 * *$ & $0.231 *$ & $0.337 * * *$ \\
\hline & 3.67 & 3.06 & 2.23 & 1.65 & 3.55 \\
\hline \multirow[t]{2}{*}{ Age $70-74$} & $0.354 * * *$ & $0.434 * * *$ & $0.277 * *$ & 0.241 & $0.415 * * *$ \\
\hline & 4.08 & 3.52 & 2.25 & 1.54 & 4.00 \\
\hline \multirow[t]{2}{*}{ Age $75+$} & $0.359 * * *$ & $0.448 * * *$ & $0.284 * *$ & $0.349 * *$ & $0.405 * * *$ \\
\hline & 4.18 & 3.76 & 2.27 & 2.29 & 3.93 \\
\hline \multicolumn{6}{|c|}{ Pension Characteristics, Income and Wealth Variables } \\
\hline \multirow[t]{2}{*}{ DC pension only } & -0.107 & -0.142 & -0.087 & 0.253 & $-0.166^{*}$ \\
\hline & -1.38 & -1.18 & -0.87 & 1.49 & -1.94 \\
\hline \multirow[t]{2}{*}{ Both DB and DC pension } & 0.080 & 0.114 & 0.050 & $0.330 * *$ & 0.038 \\
\hline & 1.22 & 1.08 & 0.59 & 2.07 & 0.52 \\
\hline \multirow[t]{2}{*}{ Undetermined pension } & -0.167 & -0.009 & -0.205 & 0.538 & $-0.364 *$ \\
\hline & -0.86 & -0.02 & -0.96 & 1.28 & -1.81 \\
\hline \multirow[t]{2}{*}{ No pension } & $-0.176^{* * *}$ & $-0.164^{*}$ & $-0.175^{* *}$ & 0.128 & $-0.223 * * *$ \\
\hline & -3.07 & -1.83 & -2.28 & 1.00 & -3.48 \\
\hline \multirow[t]{2}{*}{ Pension income/1000 } & $3.9 \mathrm{E}-4$ & 0.002 & $-3.1 E-4$ & $0.020 * * *$ & $-6.3 E-4$ \\
\hline & 0.28 & 0.59 & -0.21 & 3.11 & -0.48 \\
\hline \multirow[t]{2}{*}{ Soc Sec ret income/1000 } & -0.005 & -0.004 & -0.008 & 0.002 & -0.007 \\
\hline & -1.21 & -0.53 & -1.36 & 0.16 & -1.46 \\
\hline \multirow[t]{2}{*}{ Earnings/1000 } & $-6.9 \mathrm{E}-4$ & 0.003 & -0.002 & $0.018 * *$ & -0.003 \\
\hline & -0.25 & 0.65 & -0.69 & 2.32 & -0.84 \\
\hline \multirow[t]{2}{*}{ Other $\mathrm{HH}$ income/1000 } & $3.3 \mathrm{E}-4$ & $5.2 \mathrm{E}-4$ & $3.8 \mathrm{E}-4$ & $0.007 * *$ & $1.8 \mathrm{E}-4$ \\
\hline & 0.66 & 0.73 & 0.52 & 2.46 & 0.38 \\
\hline \multirow[t]{2}{*}{ Household Net Worth/1000 } & $7.1 \mathrm{E}-5$ & $2.6 \mathrm{E}-5$ & $1.0 \mathrm{E}-4$ & $6.8 \mathrm{E}-5$ & $6.9 \mathrm{E}-5$ \\
\hline & 1.36 & 0.32 & 1.47 & 0.23 & 1.29 \\
\hline Net Worth/1000 Squared & $-6.2 \mathrm{E}-9$ & $-2.6 \mathrm{E}-9$ & $-8.1 E-9$ & $-3.3 \mathrm{E}-8$ & $-5.9 \mathrm{E}-9$ \\
\hline & -1.33 & -0.36 & -1.40 & -0.51 & -1.24 \\
\hline
\end{tabular}


Table 4 continued

\begin{tabular}{|c|c|c|c|c|c|}
\hline \multicolumn{6}{|l|}{ Other Variables } \\
\hline \multirow[t]{2}{*}{ Forced to retire } & $-0.597 * * *$ & $-0.665 * * *$ & $-0.523 * * *$ & $-0.558 * * *$ & $-0.601 * * *$ \\
\hline & -14.52 & -11.79 & -8.65 & -6.67 & -12.83 \\
\hline \multirow[t]{2}{*}{ Partly wanted, forced ret. } & $-0.294 * * *$ & $-0.407 * * *$ & $-0.173 * *$ & -0.153 & $-0.330 * * *$ \\
\hline & -4.85 & -4.65 & -2.06 & -1.05 & -5.01 \\
\hline \multirow[t]{2}{*}{ Very good health } & -0.021 & -0.056 & -0.018 & -0.121 & -0.021 \\
\hline & -0.34 & -0.68 & -0.19 & -0.63 & -0.31 \\
\hline \multirow[t]{2}{*}{ Good health } & $-0.174 * * *$ & $-0.234 * * *$ & -0.145 & -0.138 & $-0.191 * * *$ \\
\hline & -2.85 & -2.81 & -1.58 & -0.77 & -2.90 \\
\hline \multirow[t]{2}{*}{ Fair health } & $-0.375 * * *$ & $-0.394 * * *$ & $-0.397 * * *$ & -0.257 & $-0.416 * * *$ \\
\hline & -5.67 & -4.35 & -4.08 & -1.42 & -5.74 \\
\hline \multirow[t]{2}{*}{ Poor health } & $-0.790 * * *$ & $-0.881 * * *$ & $-0.743 * * *$ & $-0.799 * * *$ & $-0.787 * * *$ \\
\hline & -9.98 & -7.79 & -6.60 & -4.12 & -8.72 \\
\hline \multirow[t]{2}{*}{ Respondent working } & $0.174^{*}$ & $0.375 * * *$ & 0.060 & 0.180 & 0.173 \\
\hline & 1.81 & 2.68 & 0.46 & 0.76 & 1.63 \\
\hline \multirow[t]{2}{*}{ Spouse working } & -0.092 & -0.058 & $-0.126^{*}$ & 0.031 & $-0.105^{*}$ \\
\hline & -1.62 & -0.65 & -1.70 & 0.24 & -1.67 \\
\hline \multirow[t]{2}{*}{ Has other health ins. only } & $0.526 * * *$ & $0.424 * * *$ & $0.669 * * *$ & $0.346 * *$ & $0.564 * * *$ \\
\hline & 6.32 & 3.66 & 5.50 & 1.97 & 5.82 \\
\hline \multirow[t]{2}{*}{ Has both govt and other health ins. } & $0.100 * *$ & 0.043 & $0.160 * * *$ & 0.015 & $0.098 * *$ \\
\hline & 2.50 & 0.76 & 2.75 & 0.15 & 2.21 \\
\hline \multirow[t]{2}{*}{ No health insurance } & $0.311 * *$ & $0.399 * *$ & 0.255 & 0.194 & $0.356 * *$ \\
\hline & 2.39 & 2.53 & 1.38 & 1.05 & 2.15 \\
\hline Chi-Squared & $924.56 * * *$ & $512.11 * * *$ & $468.38 * * *$ & $279 . .18 * * *$ & $716.30 * * *$ \\
\hline \# of Observations & 6085 & 3035 & 3050 & 1327 & 4758 \\
\hline
\end{tabular}


Table 5. Ordered Probit Regressions of Subjective Well-being by Reason of Retirement

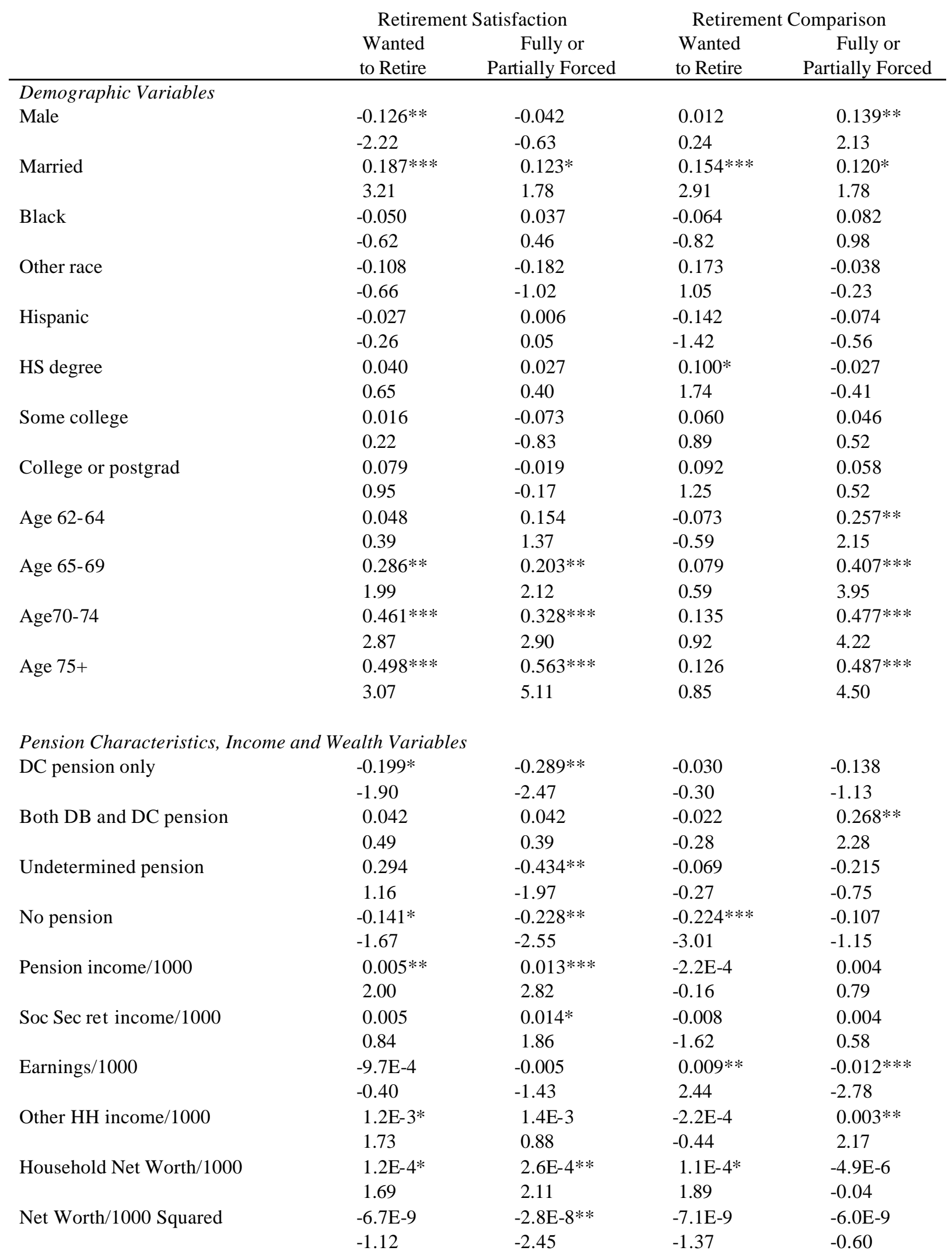


Table 5 continued

\begin{tabular}{|c|c|c|c|c|}
\hline \multicolumn{5}{|l|}{ Other Variables } \\
\hline \multirow[t]{2}{*}{ Very good health } & $-0.316^{* * *}$ & 0.042 & -0.066 & 0.101 \\
\hline & -3.27 & 0.30 & -0.91 & 0.85 \\
\hline \multirow[t]{2}{*}{ Good health } & $-0.662 * * *$ & $-0.297 * *$ & $-0.205^{* * *}$ & -0.092 \\
\hline & -6.99 & -2.26 & -2.82 & -0.81 \\
\hline \multirow[t]{2}{*}{ Fair health } & $-0.870 * * *$ & $-0.551 * * *$ & $-0.373 * * *$ & $-0.354 * * *$ \\
\hline & -8.55 & -4.09 & -4.56 & -3.01 \\
\hline \multirow[t]{2}{*}{ Poor health } & $-1.229 * * *$ & $-0.983 * * *$ & $-0.657 * * *$ & $-0.832 * * *$ \\
\hline & -10.14 & -6.66 & -5.89 & -6.55 \\
\hline \multirow[t]{2}{*}{ Respondent working } & 0.051 & 0.321 & 0.030 & $0.381 * *$ \\
\hline & 0.44 & 1.63 & 0.26 & 2.34 \\
\hline \multirow[t]{2}{*}{ Spouse working } & -0.081 & $-0.212 * *$ & -0.098 & -0.135 \\
\hline & -1.08 & -2.35 & -1.35 & -1.47 \\
\hline \multirow[t]{2}{*}{ Has other health ins. only } & $0.500 * * *$ & $0.375 * * *$ & $0.409 * * *$ & $0.601 * * *$ \\
\hline & 3.61 & 3.18 & 3.35 & 4.82 \\
\hline \multirow[t]{2}{*}{ Has both govt and other health ins. } & $0.172 * * *$ & $0.191 * * *$ & $0.112 * *$ & 0.073 \\
\hline & 3.07 & 2.83 & 2.17 & 1.09 \\
\hline \multirow[t]{2}{*}{ No health insurance } & 0.163 & 0.033 & 0.139 & $0.385 * * *$ \\
\hline & 0.79 & 0.19 & 0.69 & 2.32 \\
\hline Chi-Squared & $332.89 * * *$ & $345.42 * * *$ & $255.38 * * *$ & $284.35 * * *$ \\
\hline \# of Observations & 3986 & 2260 & 3892 & 2193 \\
\hline
\end{tabular}


Table 6. Selected Results from Various Well-being Specifications using Comparison Income

\begin{tabular}{|c|c|c|}
\hline & $\begin{array}{l}\text { Retirement } \\
\text { Satisfaction }\end{array}$ & $\begin{array}{c}\text { Retirement } \\
\text { Comparison }\end{array}$ \\
\hline \multicolumn{3}{|l|}{ Specification 1} \\
\hline Difference in total HH income & $\begin{array}{l}9.3 \mathrm{E}-4 * * * \\
(4.02)\end{array}$ & $\begin{array}{l}2.1 \mathrm{E}-4 \\
(1.27)\end{array}$ \\
\hline \multicolumn{3}{|l|}{ Specification 2} \\
\hline Dummy $=1$ if difference $>0$ & $\begin{array}{l}0.068 \text { *** } \\
(4.59)\end{array}$ & $\begin{array}{l}0.035^{* *} \\
(2.43)\end{array}$ \\
\hline \multicolumn{3}{|l|}{ Specification 3} \\
\hline Difference in pension income & $\begin{array}{l}0.003 * * * \\
(3.14)\end{array}$ & $\begin{array}{l}1.6 \mathrm{E}-4 \\
(0.28)\end{array}$ \\
\hline Difference in Soc Sec ret. income & $\begin{array}{l}0.003 * * \\
(1.97)\end{array}$ & $\begin{array}{l}-0.002 \\
(-0.92)\end{array}$ \\
\hline Difference in earned income & $\begin{array}{l}-4.5 \mathrm{E}-4 \\
(-1.22)\end{array}$ & $\begin{array}{l}-1.7 \mathrm{E}-4 \\
(-0.15)\end{array}$ \\
\hline Difference in other HH income & $\begin{array}{l}8.5 \mathrm{E}-4^{* * *} \\
(3.51)\end{array}$ & $\begin{array}{l}2.5 \mathrm{E}-4 \\
(1.36)\end{array}$ \\
\hline Specification 4 & & \\
\hline Dummy $=1$ if pension difference $>0$ & $\begin{array}{l}0.068 * * * \\
(4.38)\end{array}$ & $\begin{array}{l}0.059 * * * \\
(3.91)\end{array}$ \\
\hline Dummy $=1$ if Soc Sec difference $>0$ & $\begin{array}{l}0.027^{*} \\
(1.89)\end{array}$ & $\begin{array}{l}-1.1 \mathrm{E}-4 \\
(-0.01)\end{array}$ \\
\hline Dummy $=1$ if earned difference $>0$ & $\begin{array}{r}-0.021 \\
(-0.99)\end{array}$ & $\begin{array}{c}0.025 \\
(1.14)\end{array}$ \\
\hline Dummy $=1$ if other HH difference $>0$ & $\begin{array}{l}0.042 * * * \\
(2.71)\end{array}$ & $\begin{array}{l}0.036^{* *} \\
(2.37)\end{array}$ \\
\hline
\end{tabular}

Note: Numbers above are marginal effects of a change in the probability of being in the top satisfaction or comparison category. Other covariates in each of the four specifications include all nonincome variables in Tables 3 and 4 . *, **, *** indicate 10, 5, and 1\% significance, respectively. Numbers under coefficient estimates are asymptotic Z statistics. Regressions weighted by Wave 2000 sample weights. Results for the income regressions are given in Appendix Table 1. 
Table 7. Probit and Sample Selection Results for Subjective Well-being Measures

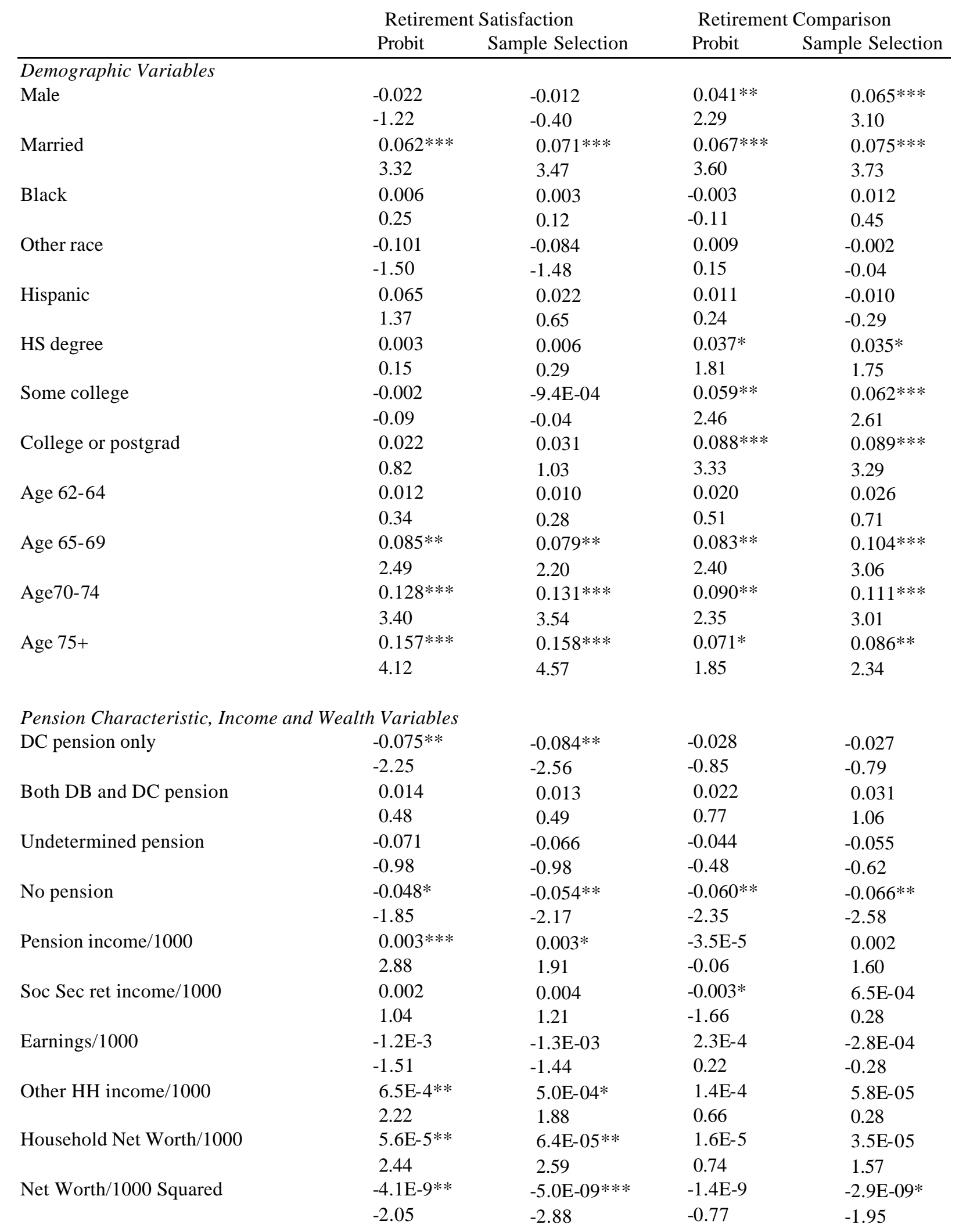


Table 7 continued

Other Variables

Forced to retire

Partly wanted, forced ret.

\begin{tabular}{|c|c|c|c|}
\hline$-0.300 * * *$ & $-0.292 * * *$ & $-0.202 * * *$ & $-0.216 * * *$ \\
\hline-16.28 & -14.39 & -10.78 & -10.13 \\
\hline$-0.192 * * *$ & $-0.194 * * *$ & $-0.118 * * *$ & $-0.119 * * *$ \\
\hline-6.97 & -7.15 & -4.33 & -4.10 \\
\hline$-0.104 * * *$ & $-0.099 * * *$ & -0.003 & -0.011 \\
\hline-3.40 & -3.34 & -0.12 & -0.40 \\
\hline$-0.246 * * *$ & $-0.242 * * *$ & $-0.050^{*}$ & $-0.067 * *$ \\
\hline-8.23 & -7.88 & -1.85 & -2.37 \\
\hline$-0.337 * * *$ & $-0.328 * * *$ & $-0.119 * * *$ & $-0.129 * * *$ \\
\hline-10.60 & -10.23 & -4.06 & -4.16 \\
\hline$-0.417 * * *$ & $-0.421 * * *$ & $-0.228 * * *$ & $-0.262 * * *$ \\
\hline-11.31 & -12.34 & -6.62 & -7.46 \\
\hline 0.068 & 0.062 & 0.063 & 0.006 \\
\hline 1.65 & 1.07 & 1.51 & 0.13 \\
\hline$-0.056 * *$ & $-0.062 * *$ & $-0.041 *$ & $-0.054 * *$ \\
\hline-2.29 & -2.07 & -1.69 & -2.02 \\
\hline $0.165 * * *$ & $0.166 * * *$ & $0.195 * * *$ & $0.182 * * *$ \\
\hline 4.92 & 4.89 & 5.49 & 5.07 \\
\hline $0.076 * * *$ & $0.074 * * *$ & $0.044 * *$ & 0.028 \\
\hline 4.12 & 4.21 & 2.38 & 1.45 \\
\hline $0.091 *$ & 0.074 & $0.124 * *$ & $0.109 * *$ \\
\hline 1.71 & 1.52 & 2.27 & 2.14 \\
\hline $1127.21 * * *$ & $1078.11 * * *$ & $639.02 * * *$ & $760.20 * * *$ \\
\hline \multirow[t]{2}{*}{6246} & 16,782 & 6072 & 16,621 \\
\hline & 0.18 & & $5.53 * *$ \\
\hline
\end{tabular}

Very good health

Good health

Fair health

Poor health

Respondent working

Spouse working

Has other health ins. only

Has both govt and other health ins.

No health insurance

$?^{2}$ statistic

\# of observations

0.18

$?^{2}$ test for independence (selection)

Note: Coefficients are marginal effects. Includes eight regional variables and a constant term. *,**,*** indicate 10,5 , and $1 \%$ significance, respectively. Numbers under coefficient estimates are asymptotic Z statistics. Estimates are weighted by Wave 2000 sample weights. Results for the fully retired sample selection regressions are given in Appendix Table 2. 
Appendix Table 1. Income OLS Regressions for Relative Earnings Regressions

\begin{tabular}{|c|c|c|c|c|c|}
\hline & Total HH & Pension & Soc Sec & Earned & Other HH \\
\hline \multirow[t]{2}{*}{ Male } & -0.227 & $3.684 * * *$ & $2.723 * * *$ & $12.792 * * *$ & $-14.008 * * *$ \\
\hline & -0.17 & 17.80 & 30.58 & 11.88 & -11.36 \\
\hline \multirow[t]{2}{*}{ Married } & $17.769 * * *$ & -0.302 & $-1.388 * * *$ & $-3.712 * *$ & $21.112 * * *$ \\
\hline & 15.08 & -1.32 & -14.68 & -2.53 & 22.36 \\
\hline \multirow[t]{2}{*}{ Black } & $-7.963 * * *$ & -0.081 & $-1.288 * * *$ & $-3.631 * * *$ & $-7.832 * * *$ \\
\hline & -6.94 & -0.41 & -9.89 & -3.97 & -7.82 \\
\hline \multirow[t]{2}{*}{ Other race } & $-9.690 * *$ & $-1.505 * * *$ & $-1.991 * * *$ & -2.291 & $-6.884 * *$ \\
\hline & -2.32 & -3.80 & -6.49 & -0.85 & -2.17 \\
\hline \multirow[t]{2}{*}{ Hispanic } & $-10.588 * * *$ & -0.427 & $-2.042 * * *$ & -1.686 & $-7.620 * * *$ \\
\hline & -7.06 & -1.60 & -12.01 & -0.64 & -4.63 \\
\hline \multirow[t]{2}{*}{ HS degree } & $7.559 * * *$ & $1.898 * * *$ & $0.710 * * *$ & 0.675 & $3.409 * * *$ \\
\hline & 7.04 & 13.04 & 7.32 & 1.15 & 4.43 \\
\hline \multirow[t]{2}{*}{ Some college } & $16.110 * * *$ & $3.272 * * *$ & $0.903 * * *$ & $4.126 * * *$ & $12.308 * * *$ \\
\hline & 11.03 & 10.49 & 7.39 & 4.45 & 10.13 \\
\hline \multirow[t]{2}{*}{ College or postgrad } & $40.392 * * *$ & $6.779 * * *$ & $1.015 * * *$ & $22.396 * * *$ & $31.503 * * *$ \\
\hline & 16.43 & 18.32 & 7.00 & 10.49 & 13.86 \\
\hline \multirow[t]{2}{*}{ Age $62-64$} & 1.549 & $1.213 * * *$ & & $-3.097 *$ & -1.495 \\
\hline & 0.37 & 3.98 & & -1.71 & -0.65 \\
\hline \multirow[t]{2}{*}{ Age $65-69$} & $-4.178 * *$ & $2.064 * * *$ & $3.316 * * *$ & $-11.724 * * *$ & $-3.889 * *$ \\
\hline & -1.72 & 6.74 & 22.30 & -9.15 & -2.28 \\
\hline \multirow[t]{2}{*}{ Age70-74 } & $-7.272 * * *$ & $1.722 * * *$ & $4.181 * * *$ & $-11.731 * * *$ & $-6.114 * * *$ \\
\hline & -3.05 & 5.40 & 27.68 & -5.34 & -3.14 \\
\hline \multirow[t]{2}{*}{ Age $75+$} & $-8.271 * * *$ & $0.911 * * *$ & $4.133 * * *$ & $-12.458 * * *$ & $-6.104 * * *$ \\
\hline & -3.67 & 2.77 & 28.27 & -8.52 & -3.72 \\
\hline \multirow[t]{2}{*}{ Respondent working } & -1.451 & $-3.407 * * *$ & $-0.109 * *$ & $28.955 * * *$ & $-4.903 * *$ \\
\hline & -0.57 & -14.59 & -2.45 & 24.52 & -2.56 \\
\hline \multirow[t]{2}{*}{ Spouse working } & $20.493 * * *$ & $-0.876 * * *$ & $-0.845 * * *$ & 0.403 & $24.730 * * *$ \\
\hline & 7.56 & -3.37 & -7.06 & 0.30 & 14.41 \\
\hline \multirow[t]{2}{*}{ Number of household residents } & $-2.184 * * *$ & $-0.302 * * *$ & $-0.371 * * *$ & -0.282 & $-2.636 * * *$ \\
\hline & -4.41 & -4.53 & -2.88 & -0.65 & -6.22 \\
\hline \multirow[t]{2}{*}{ Constant } & $20.755 * * *$ & 1.455 & $4.038 * * *$ & $8.374 * * *$ & $19.706 * * *$ \\
\hline & 7.64 & 1.50 & 15.63 & 3.07 & 5.19 \\
\hline $\mathrm{R}$ squared & 0.20 & 0.08 & 0.23 & 0.16 & 0.15 \\
\hline
\end{tabular}

Notes: Also included, but not reported, are eight regional indicators. *, **, *** indicate 10, 5, and 1\% significance, respectively. Numbers under coefficient estimates are t-statistics. Estimates are weighted by Wave 2000 sample weights. 
Appendix Table 2. Sample Selection Regression Results for Fully Retired Regression

\begin{tabular}{|c|c|c|c|c|c|}
\hline Variable & $\begin{array}{l}\text { Retirement } \\
\text { Satisfaction }\end{array}$ & $\begin{array}{l}\text { Retirement } \\
\text { Comparison }\end{array}$ & Variable & $\begin{array}{l}\text { Retirement } \\
\text { Satisfaction }\end{array}$ & $\begin{array}{c}\text { Retirement } \\
\text { Comparison }\end{array}$ \\
\hline \multirow[t]{2}{*}{ Male } & $0.521 * * *$ & $0.516^{* * *}$ & Net Worth/1000 Squared & $-4.4 \mathrm{E}-9$ & $-4.9 \mathrm{E}-9$ \\
\hline & 17.95 & 17.51 & & -1.30 & -1.40 \\
\hline \multirow[t]{2}{*}{ Married } & $0.070 * *$ & $0.073 * *$ & Very good health & 0.018 & 0.021 \\
\hline & 2.40 & 2.48 & & 0.40 & 0.45 \\
\hline \multirow[t]{2}{*}{ Black } & $0.124 * * *$ & $0.115 * * *$ & Good health & -0.069 & -0.058 \\
\hline & 2.98 & 2.73 & & -1.51 & -1.25 \\
\hline \multirow[t]{2}{*}{ Other race } & 0.066 & 0.071 & Fair health & -0.061 & -0.051 \\
\hline & 0.74 & 0.85 & & -1.28 & -1.07 \\
\hline \multirow[t]{2}{*}{ Hispanic } & $-0.184 * * *$ & $-0.182 * * *$ & Poor health & $-0.162 * * *$ & $-0.152 * * *$ \\
\hline & -2.79 & -3.17 & & -2.96 & -2.78 \\
\hline \multirow[t]{2}{*}{ HS degree } & $0.127 * * *$ & $0.118 * * *$ & Respondent working & $-1.851 * * *$ & $-1.761 * * *$ \\
\hline & 4.11 & 3.78 & & -35.16 & -31.85 \\
\hline \multirow[t]{2}{*}{ Some college } & $0.231 * * *$ & $0.227 * * *$ & Spouse working & $-0.240 * * *$ & $-0.231 * * *$ \\
\hline & 6.05 & 5.94 & & -6.46 & -6.08 \\
\hline \multirow[t]{2}{*}{ College or postgrad } & $0.273 * * *$ & $0.264 * * *$ & Born in mid Atl region & -0.006 & -0.016 \\
\hline & 6.10 & 5.86 & & -0.08 & -0.21 \\
\hline \multirow[t]{2}{*}{ Age $62-64$} & $0.249 * * *$ & $0.238 * * *$ & Born in ENC region & -0.082 & -0.080 \\
\hline & 4.63 & 4.28 & & -1.01 & -1.01 \\
\hline \multirow[t]{2}{*}{ Age 65-69 } & $0.463 * * *$ & $0.457 * * *$ & Born in WNC region & 0.031 & -0.012 \\
\hline & 9.55 & 9.32 & & 0.34 & -0.13 \\
\hline \multirow[t]{2}{*}{ Age70-74 } & $0.399 * * *$ & $0.410 * * *$ & Born in South Atl region & $-0.148^{*}$ & $-0.152 * *$ \\
\hline & 7.49 & 7.68 & & -1.82 & -1.98 \\
\hline \multirow[t]{2}{*}{ Age $75+$} & $0.181 * * *$ & $0.195^{* * *}$ & Born in ESC region & $0.160^{*}$ & $0.156^{*}$ \\
\hline & 3.67 & 3.95 & & 1.78 & 1.79 \\
\hline \multirow[t]{2}{*}{ Pension income/1000 } & $0.012 * * *$ & $0.013 * * *$ & Born in WSC region & -0.015 & -0.033 \\
\hline & 5.83 & 6.21 & & -0.17 & -0.37 \\
\hline \multirow[t]{2}{*}{ Soc Sec ret income $/ 1000$} & $0.040 * * *$ & $0.038 * * *$ & Born in Mountain region & $0.188^{*}$ & 0.133 \\
\hline & 13.13 & 12.51 & & 1.69 & 1.20 \\
\hline \multirow[t]{2}{*}{ Earnings/1000 } & $-0.011 * * *$ & $-0.015 * * *$ & Born in Pacific region & -0.021 & -0.032 \\
\hline & -7.70 & -7.73 & & -0.21 & -0.33 \\
\hline \multirow[t]{2}{*}{ Other HH income/1000 } & $-1.2 \mathrm{E}-3 * * *$ & $-1.2 \mathrm{E}-3 * * *$ & Born outside US & -0.051 & -0.055 \\
\hline & -2.77 & -2.67 & & -0.55 & -0.68 \\
\hline \multirow[t]{2}{*}{ HH Net Worth/1000 } & $6.8 \mathrm{E}-5^{*}$ & $7.6 \mathrm{E}-5^{*}$ & & & \\
\hline & 1.69 & 1.82 & & & \\
\hline
\end{tabular}

Note: Results from a maximum likelihood estimation of a bivariate probit model with sample selection. * *,*, *** indicate 10, 5, and 1\% significance, respectively. Numbers under coefficient estimates are asymptotic $\mathrm{Z}$ statistics. Results for the retirement well-being regressions are given in Table 7. 


\section{RECENT WORKING PAPERS FROM THE \\ CENTER For RETIREMENT Research AT Boston College}

The Well-Being Of Retirees: Evidence Using Subjective Data

Keith A. Bender, November 2004

The Impact of Aging on Financial Markets and the Economy: A Survey

Barry P. Bosworth, Ralph C. Bryant and Gary Burtless, October 2004

Social Security Personal-Account Participation with Government Matching

Gary V. Engelhardt and Anil Kumar, October 2004

Providing Guarantees in Social Security

Karen E. Smith, C. Eugene Steuerle, and Pablo Montagnes, August 2004

Deferring Income in Employer-Sponsored Retirement Plans: The Dynamics of Participant Contributions

Karen E. Smith, Richard W. Johnson, and Leslie A. Muller, August 2004

Reform Model Two of the President's Commission to Strengthen Social Security: Distributional Outcomes Under Different Economic and Behavioral Assumptions Melissa M. Favreault, Joshua H. Goldwyn, Karen E. Smith, Lawrence H. Thompson, Cori E. Uccello, and Sheila R. Zedlewski, August 2004

An Analysis of How Individuals React to Market Returns in One 401(k) Plan Julie Agnew, April 2004

The Effects of Health Insurance and Self-Insurance on Retirement Behavior Eric French and John Bailey Jones, April 2004

Valuing Assets in Retirement Saving Accounts

James M. Poterba, April 2004

Lifetime Earnings, Social Security Benefits, and the Adequacy of Retirement Wealth Accumulation

Eric M. Engen, William G. Gale, and Cori Uccello, April 2004

The Effect of Social Security on Divorce and Remarriage Behavior Stacy Dickert-Conlin and Cristian Meghea, April 2004

All working papers are available on the Center for Retirement Research website (http://www.bc.edu/crr) and can be requested by e-mail (crr@bc.edu) or phone (617-552-1762). 